First Peoples Child \& Family Review

A Journal on Innovation and Best Practices in Aboriginal Child Welfare Administration,

Research, Policy \& Practice

\title{
Loss of Trust Among First Nation People: Implications when Implementing Child Protection Treatment Initiatives
}

\section{Steven Thibodeau and Faye North Peigan}

\section{Volume 3, Number 4, 2007}

URI: https://id.erudit.org/iderudit/1069374ar

DOI: https://doi.org/10.7202/1069374ar

See table of contents

Publisher(s)

First Nations Child and Family Caring Society of Canada

ISSN

1708-489X (print)

2293-6610 (digital)

Explore this journal

Cite this article

Thibodeau, S. \& Peigan, F. (2007). Loss of Trust Among First Nation People: Implications when Implementing Child Protection Treatment Initiatives. First Peoples Child \& Family Review, 3(4), 50-58. https://doi.org/10.7202/1069374ar
Article abstract

Social workers and other health care providers have been asked to develop and implement innovative and culturally sensitive treatment initiatives in First Nation communities. However, because of traumatization and oppression, many First Nations people face troubling psycho-social issues which have resulted in a diminished capacity to trust. If this loss of trust is not dealt with skillfully, it can impede the ability of social workers to implement initiatives. Through a process of person-centred interviewing, 36 participants identified four levels of trust that have been diminished among many First Nations people. The impact of this phenomenon on the development and implementation of community based initiatives is discussed in this article.
This document is protected by copyright law. Use of the services of Érudit (including reproduction) is subject to its terms and conditions, which can be viewed online.

https://apropos.erudit.org/en/users/policy-on-use/ 


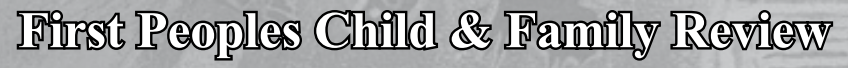

A Journal on Innovation and Best Practices in Aboriginal Child Welfare Administration, Research, Policy \& Practice

Volume 3, Number 4, 2007, pp. 50-58

\title{
Loss of Trust Among First Nation People: Implications when Implementing Child Protection Treatment Initiatives
}

\author{
Steven Thibodeau and Faye North Peigan ${ }^{\mathrm{b}}$
}

\begin{abstract}
a Steven Thibodeau, PhD, MSW, RSW, started his career as a child protection worker in southern Alberta. Steven then ventured into clinical practiced and for many years was the mental health coordinator and researcher with several First Nation communities. More recently he joined the faculty of the School of Health Sciences at the University of Lethbridge in the Addiction Counseling Program. Steven continues to provide mental health services to First Nations people in southern Alberta.

${ }^{b}$ Faye North Peigan BN, MA, has a Master of Arts Degree in Teaching and Counseling from Gonzaga University. She also has a Bachelor of Nursing Degree from the University of Lethbridge. Faye was the CEO of Aakom-Kiyii Heath Services in Brocket, Alberta for ten years. She currently is a health consultant with Morning Star Consulting. She can be reached at 403-965-2428, fax: 403 965-2617 and/or morningstar7@telus.net.
\end{abstract}

\section{Introduction}

Building on early research (Thibodeau, 2003), this article outlines the results of interviews with social workers and other health care providers. Participants identified four levels of trust that have been diminished or lost by community members living on First Nations reserves. This phenomenon can have an impact on the development and delivery of community based treatment initiatives by health care professionals. Included in this article are broad strategies and recommendations that social workers can employ to allay these concerns.

Questions or correspondence concerning this article may be addressed to:

Steven Thibodeau, PhD, MSW, RSW

Marriage and Family Therapist, AAMFT

Associate Professor School of Health Sciences

University of Lethbridge, Alberta

Phone: 403 332-5234

steven.thibodeau@uelth.ca

\begin{abstract}
Abstract:

Social workers and other health care providers have been asked to develop and implement innovative and culturally sensitive treatment initiatives in First Nation communities. However, because of traumatization and oppression, many First Nations people face troubling psycho-social issues which have resulted in a diminished capacity to trust. If this loss of trust is not dealt with skillfully, it can impede the ability of social workers to implement initiatives. Through a process of person-centred interviewing, 36 participants identified four levels of trust that have been diminished among many First Nations people. The impact of this phenomenon on the development and implementation of community based initiatives is discussed in this article.
\end{abstract}

\section{Literature Review}

A challenge facing social workers and other health care professionals is designing services that are can provide meaningful assistance to families who are under their purview (Callahan, 1993; Cameron, 2003). Theorists indicate that while practitioners in the field of child welfare focus on child protection and the provision of programs that are reactive, future efforts should move toward community based programs that promote family wellness and provide supports for parents (Callahan, 1993; Collier, 1993; Wharf, 1993). To meet this expectation, social workers need to be more inclusive, flexible, and truly responsive to the immediate needs of families and their communities (Geoffrion \& Scarth, 1995). This is particularly true for First Nations communities (Proulx \& Perrault, 2000; RCMP, 1996). Regrettably, child welfare systems have not always acted in the best interest of First Nations people and as early as 1985 there were calls to re-evaluate the relationship between child welfare systems and First Nations communities (McKenzie \& Hudson, 1985). As a result, innovative community based initiatives 


\section{First Peoples Child \& Family Review, Volume 3, Number 4, 2007}

have emerged that focus on strengthening the family by providing such programs as parent support groups and treatment groups for abusive partners (Pecora, 1995). These initiatives have been of demonstrable value (Wharf, 1993). However, social workers must be respectful and informed when implementing such initiatives in First Nations communities. Historically, First Nations people have experienced considerable trauma (Proulx \& Perrault, 2000), resulting from well documented accounts of oppression and marginalization (RCAP, 1996). These traumatic experiences have had profoundly negative effects on the psycho-social well-being of entire generations of First Nations people (LaRocque, 1993), and have interfered with their ability to establish trusting relationships (Thibodeau, 2003). Trust has been defined as, "a state of favorable expectation regarding other people's actions and intentions" (Simmel, as quoted in Mollering, 2001 p.403).

Such a diminished ability to trust can have far reaching effects on family functioning, and on community capacity and its ability to endorse community based initiatives (Goodman, R.M. et al. 1998). Fukuyama (1995) who has worked extensively in the area of trust, states, "We often take a minimal level of trust and honesty for granted and forget that they pervade everyday economic life and are critical to its smooth functioning (p.152). Mollering (2001) cautions that, “... without the general trust that people have in each other, society itself would disintegrate" (p. 178) and goes on to clarify that, "Trust's function manifests itself at all levels of society" (p.405). Earlier research has suggested that trust has been diminished at four levels of society in First Nations communities (Thibodeau, 2003). These levels include a lack of trust at a personal level. Matsakis (1998, p.57) describes the connection between traumatization and a loss of trust in oneself:

Trauma survivors not only lose trust in some of the basic premises that keep people functioning such as the assumptions of personal invulnerability and that the world is just and fair but they can also lose trust in people, including themselves.

There can also be loss of family unity, where individuals cannot turn to family members for support in light of maltreatment and victimization within the family (Thibodeau, 2003). The seriousness of this loss becomes clear as First Nations people place a premium on family and clan ties (Crowshoe \& Manneschmidt, 2002). Additionally, "First Nations people value family ties and relationships above all else, except their creator" (Supernault 1996, p.97). However, many people have been maltreated and dishonored within the family (LaRocque, 1993) resulting in a diminished level of trust within that domain. Trust has also being diminished at the community level, between family and clan members within the same community (Thibodeau, 2003). This stems in part from extended family quarrels and issues related to abuse between families (Kiyoshk, 1996). Finally there is a lack of trust in government departments and outsiders (Thibodeau, 2003). An outsider is generally viewed as one who is not from the community; this could include a First Nations person from a different community or a non-First Nations person. Supporting literature indicates that there is considerable mistrust and bitterness directed at the Government of Canada (Proulx \& Perrault, 200; LaRocque, 1993) as well as with outsiders generally (Lee, 1997). A diminished ability to trust has significant implications for the development and implementation of community based treatment initiates, as trust is a core value when implementing social initiatives (Matsakis, 1998).

\section{Method}

Person centred interviewing and observation was used as a method of ethnographic inquiry, where the interplay of social and personal forces was considered. That is, person centred interviews engage the interviewee as both the informant, a knowledgeable person who can elucidate about culture and behaviour in a particular locale and as the participant, "as an object of systematic study and observation in him or herself" ( Levy \& Hollan, 1998 p. 335). Ethical review and approval for this research was provided by facility of Social Science and Law, University of Manchester, UK.

\section{Participants}

The sample was comprised of 36 participants employed in one of eight First Nations Reserves in Alberta. A total of $71 \%$ of the participants identified themselves as being a First Nations person, while $65 \%$ spoke an First Nations language. About half of the participants identified themselves as social workers, while the remaining participants were professional or paraprofessional community workers. Participants were selected using purposive sampling, "[a]sampling procedure that utilizes intentional but not random processes" (Cournoyer \& Klein, 2000 p. 261) and that "purposefully select participants ... that will best help the researcher understand the problem and the research question" (Creswell, 2003 p. 185). Important characteristics of participants included: (1) they were professional or paraprofessional health care professionals implementing a psycho-social treatment initiative on a First Nations Reserve in Alberta; and (2) they lived and/or worked on a First Nations reserve for at least two years. 


\begin{tabular}{|c|c|c|c|}
\hline \multicolumn{2}{|l|}{ Variable } & N & $\%$ of sample \\
\hline Raised on Reserve & $\begin{array}{l}\text { Yes } \\
\text { No }\end{array}$ & $\begin{array}{l}27 \\
9\end{array}$ & $\begin{array}{l}74.29 \\
25.71\end{array}$ \\
\hline Profession & $\begin{array}{l}\text { Social Worker } \\
\text { Community Worker } \\
\text { Other }\end{array}$ & $\begin{array}{l}18 \\
15 \\
3\end{array}$ & $\begin{array}{l}50.3 \\
41.6 \\
8.2\end{array}$ \\
\hline Years on Reserve & $\begin{array}{l}2 \text { to } 4 \text { years } \\
5 \text { to } 10 \text { years } \\
11 \text { or more years }\end{array}$ & $\begin{array}{l}9 \\
8 \\
19\end{array}$ & $\begin{array}{l}25.71 \\
22.86 \\
51.43\end{array}$ \\
\hline Education & $\begin{array}{l}\text { Some High School } \\
\text { Completed High School } \\
\text { Post Secondary }\end{array}$ & $\begin{array}{l}3 \\
5 \\
28\end{array}$ & $\begin{array}{l}5.71 \\
14.29 \\
80.00\end{array}$ \\
\hline
\end{tabular}

\section{Data Collection}

In-depth semi-structured interviews, each lasting between one and three hours, were conducted on eight First Nations sites in Alberta between 1999 and 2001. An interview guide with a grand tour question and secondary questions was employed. The grand tour question was: What factors need to be considered when implementing treatment initiatives in your community? The audio-taped interviews were conducted by a co- interviewing team; a First Nations female and a non-First Nations male. Such an 'insider outsider' interviewing team is a recommended interviewing method when working cross culturally (Deutsch, 1981; Labaree, 2002). The research team was aware that sensitive issues, such as family violence and child abuse might arise during the interviewing process (McCosker, Bernard \& Gerber, 2001). The team was prepared to address those occurrences by employing an insider outsider team, providing the services of mental health professionals or local elders if required, stressing the importance of confidentiality and anonymity, and emphasizing the voluntary nature of their involvement (Reichardt \& Cook, 1992). During the guided interviews, the team explored and identified salient factors when implementing community based treatment initiatives in their communities.

\section{Data Analysis}

The purpose of the qualitative analysis was to code data so that thematic categories would be recognized by participants and analyzed behaviours noted (Field $\&$ Morse, 1985). The research team used open coding to identifying meaningful statements that led to axial coding and the establishment of categories and themes based on aggregated coded data (Patton, M., 1990; Strauss \& Corbin, 1998). The resulting categories were then scrutinized by the research team for redundancy. Analysis of data was supported by the software program NVivo. The interviews were transcribed verbatim by a professional transcriptionist. Five interview transcripts were verified for accuracy by comparing them to the taped interviews. Once the data were summarized these finding were provided to four participants to ensure that comprehensiveness, accuracy and general fit had been achieved. The purpose of this technique, known as a member check (Strauss \& Corbin, 1998) was to determine authenticity, that is, if, "the findings of the study make sense? Are they credible to the people we study and to our readers? Do we have an authentic portrait of what we were looking at?" (Miles \& Huberman, 1994, p.270). Member checks were not undertaken at four sites given their distance and isolation. Participants' responses were then included in the original data set or used to assist in revising it.

\section{Findings}

Participants indicated that there was a pervasive lack of trust in First Nations communities at every stratum of their communities, but particularly within the family. Participants noted diminished trust at four levels; trust in self, family/clan, community, and governments and outsiders. They also identified five strategies that social workers and other health care providers can employ to mitigate this phenomenon when implementing community based initiatives.

\section{Loss of Trust}

As participants discussed implementing treatment initiatives on reserves, the concept of trust and more specifically the loss of trust was a common and recurrent theme. Generally, the absence of trust was a troubling 


\section{First Peoples Child \& Family Review, Volume 3, Number 4, 2007}

issue for many participants. They cited a number of historical and social reasons that have contributed to this phenomenon, including broken treaties with the Government of Canada, the Indian Act, systemic racism and the residential school experience. Many participants emphasized trauma that resulted from residential school experiences where First Nations children learned to 'build walls' and not share information (see Bineziikwe, $2005)$. Of the 36 participants, thirty ( $85 \%)$ spontaneously identified this theme at least once in their interview. The negative impact that residential schools have had on trust is succinctly expressed by an First Nations social worker:

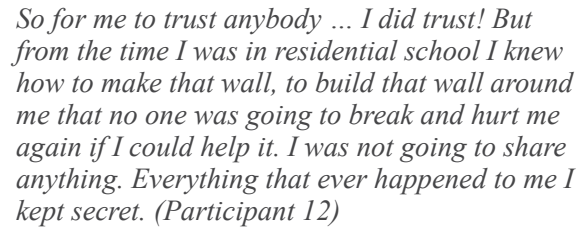

An elderly Cree social worker described her ongoing struggle with trust: "My goodness sakes, all my life, for myself this is me, all my life, every time I'd trust I was hurt, especially going back to the mission school [residential school]" (Participant 36). Participants indicated that although First Nations children were no longer attending residential schools, there were second and third generations of people who are experiencing the residual effects of that experience. Participants indicated that children learned from their parents to not trust, to be cautious and to build walls. As a result, individuals, families, clans and entire communities were found lacking the capacity to fully trust themselves and others. A First Nations worker explained this process:

$$
\begin{aligned}
& \text { People don't trust. I think in [this First Nations] } \\
& \text { community there's no trust here. They've been } \\
& \text {... people have been so badly hurt and betrayed } \\
& \text { and things in their past life, right from childhood } \\
& \text { and maybe even their parents who learned not } \\
& \text { to trust, that that's put into the children and you } \\
& \text { grow up not trusting anybody... (Participant } 8 \text { ) }
\end{aligned}
$$

This participant's statement highlights the consequences of this phenomenon on the functioning of family and community. From an early age children experience the pains of diminished trust, which were then echoed by some parents.

The following sections examine the concept of loss of trust at levels that were identified by participants, which include self, family and clan, extended community, and government and outsiders.

\section{Trust In Self}

Participants indicated that as a result of personal trauma there has been a pervasive loss of trust among First Nation people at the most primary level, a lack of trust in self. They indicated that trust at this level refers to one's ability to set and respect personal boundaries, to maintain control over one's behavior, to have faith in one's judgment, and to take responsibility for one's actions. This phenomenon and the resulting characteristics are aptly described by a First Nations social planner:

$$
\begin{aligned}
& \text { Yeah, cause, you know, it's like you're raised } \\
& \text { in a home where there's so much violence } \\
& \text { and if they say - 'no kids, you're not going to } \\
& \text { drink' and they [parents] come home drunk } \\
& \text { and 'no kids, I'm not going to beat your mom } \\
& \text { up anymore' and then he's [father] still beating } \\
& \text { her, pretty soon the kids don't even trust their } \\
& \text { own parents. And then they're left with a } \\
& \text { babysitter and maybe there's sexual abuse. } \\
& \text { They learn not even to trust people, you know, } \\
& \text { they don't, or there's incest in the family, like } \\
& \text { trust is something that's so foreign to them and } \\
& \text { so, I don't know, they don't know how to set } \\
& \text { personal boundaries, eh? They don't even trust } \\
& \text { themselves. So I think as they're evolving as } \\
& \text { individuals that trust, it takes a long time for } \\
& \text { people to trust someone else and eventually just } \\
& \text { to trust themselves. (Participant 16) }
\end{aligned}
$$

Participants indicated that a loss of trust in self appeared to limit how they engaged in daily events and life in general. This diminished level of trust limited the quality and depth of their participation in a range of activities, such as refusing to take personal risks and being absent, just being “... out of the way”. It is this lack of trust in self that hinders the development of trust in others, whether they are family, community or outsiders.

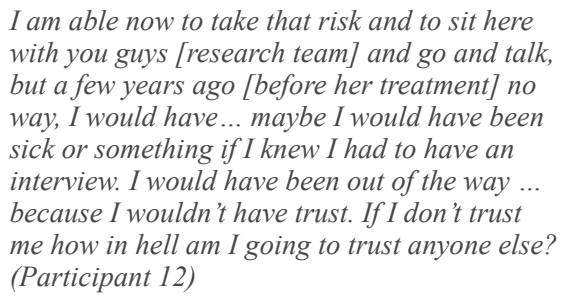

\section{Trust In Immediate Family and Clan}

The data indicate that trust has also been lost among immediate family and clan members. As noted earlier, First Nations people value family ties. However, several female First Nations participants reported that many First Nations families were not healthy. They reported that their communities were replete with stories of maltreatment and dishonor by parents, spouses, siblings, cousins and other family members. This in turn has interfered with the normal development of trust within the family. This is not to make the claim that participants did not identify strong and revered families within First Nations communities. Rather, they reported that there are many 'good' families that have embraced their traditional ways which enrich 


\section{Loss of Trust Among First Nation People}

their communities. But the view of many participants, notably First Nations females, was that some First Nations families have not been bastions of safety and support. The following quote illustrates the level of trust that has been violated and the impact this has had on family functioning.

$$
\begin{aligned}
& \text { Because-um-well when you look at, you know, } \\
& \text { the violence in the home, like little children, } \\
& \text { they learn to not even trust their parents. Cause } \\
& \text { these people [First Nations People from her } \\
& \text { community] never trusted people for a long } \\
& \text { time, some of them. Like you know, this person } \\
& \text { that you trust, like, your partner or your dad, } \\
& \text { like, is beating you up, like, so you're not } \\
& \text { going to trust, like, I'm not going to trust you } \\
& \text { [non-First Nations social worker] right away. } \\
& \text { (Participant 14) }
\end{aligned}
$$

Participants indicated that this phenomenon has impacted the functioning of many First Nations people because they lack a reference point of love, acceptance and safety and as a result have left some feeling apathetic, despondent and hopeless. One woman reflects on the deep sense of hopelessness experienced by many people from her community:

I think there's ... there's not a feeling like there's going to be a better day. Like there's better days ahead. I don't think people have a sense of that.

They just think this is it; it doesn't get any better. ... a [sense of] hopelessness (Participant 16)".

A loss of trust in the immediate family and clan made it difficult for many First Nations people to believe that there will be a better future. Participants argued that it is this pervasive demoralization, this sense of hopelessness precipitated a disinterest in their future, in the family and their community.

\section{Trust in Community}

An additional level of diminished trust identified by participants was between families and members of various clans from the same community or reserve. This community-wide discord is illustrated below:

$$
\begin{aligned}
& \text {... only recently, ... just this last fall ... there was } \\
& \text { so much mistrust because you have polarization } \\
& \text { of families, you know, saying - well, I'm for this } \\
& \text { side and I'm for that side. And that caused a lot } \\
& \text { of mistrust.... (Participant } 35 \text { ) }
\end{aligned}
$$

Another participant commented,

$$
\begin{aligned}
& \text { "Because it's such a small community. It's } \\
& 560 \text { people. Everybody's somehow related to } \\
& \text { somebody. There's a lot of clan wars there. They } \\
& \text { don't trust anyone." (Participant 13) }
\end{aligned}
$$

Participants indicated that sometimes community members could not turn to other families or clan members within their community for support or understanding in light of this 'warring' and lack of trust. Conflict at this level fostered the building of walls. Further, community members did not openly accept others from their reserve. As a result, program participants have not always experienced a welcoming and inclusive group experience. Simply put, a community member may not participate in a treatment initiative if a rival clan member is present. An elderly First Nations social worker reported:

$$
\begin{aligned}
& \text { Within the community here we have groups } \\
& \text { of people or families and clans, and not all } \\
& \text { the clans get along. Sometimes it's not so } \\
& \text { bad, sometimes it's not so good but ... there } \\
& \text { are definite walls there. So trying to do group } \\
& \text { projects or group counseling doesn't work too } \\
& \text { well a lot of time ... people will not attend if } \\
& \text { they know someone's going to be there that they } \\
& \text { don't want to be with; they won't come. And it } \\
& \text { was that way for a lot of community activities. } \\
& \text { (Participant 26) }
\end{aligned}
$$

In addition to affecting the willingness of individuals to participate in treatment initiatives, such fractious and divisive behavior can thwart a cooperative and collaborative working relationship among professions working within the same agency or between agencies.

Based on reports from participants, it appears that a lack of trust at the community level can have significant ramifications. On an individual level it can pit individuals against individuals, making it difficult to recruit and retain participants for specific initiatives. On an agency level, it can hamper collaboration among workers at the same agency or other agencies

\section{Trust in Government and Outsiders}

Finally, participants indicated that there is a general lack of trust in government departments and outsiders. An outsider is one who is not from the community; this may be an First Nations person from a different community or a non-First Nations person. Although participants suggested that First Nations people ostensibly have greater trust in outsiders than they do in their own people, several participants indicated that caution must be taken by outsiders so as not to be drawn into a false sense of acceptance.

$$
\begin{aligned}
& \text { Well, I think, like almost any other First Nations } \\
& \text { community, when you look at the history of } \\
& \text { what's gone down in most of those communities, } \\
& \text { [referring to: residential school, Indian Act, } \\
& \text { broken treaties and other oppressive government } \\
& \text { policies] people don't have any reason certainly } \\
& \text { to trust government or outsiders coming into the } \\
& \text { community ... (Participant 31). }
\end{aligned}
$$

Granted, outsiders may be seen as offering a degree of anonymity and confidentiality: 


\section{First Peoples Child \& Family Review, Volume 3, Number 4, 2007}

Because we, there's so much rumoring and gossiping, you know, when you live in the community. So when you have an outside person, you know that what you say to them, there's less likely the chance that they're going to repeat it amongst other people cause you know that person is going to leave at the end of the day and has their own life and does things and they're not into this meddling and, you know, being the first one to say something. (Participant 16)

However, outsiders must be cautious. Trust must be earned, "So their trust for other people is not there. ... So people [outsiders] have to prove themselves to people [from her community]." (Participant 7)

\section{Implications for the Social worker}

Participants suggested five broad strategies that may mitigate the impact of diminished or lost trust when implementing treatment initiatives. The following should not be viewed as an exhaustive list but as a point of departure to define and extend actions to be taken to more fully address this issue.

\section{Know the Community}

Participants have suggested that social workers should try to 'earn' the trust of families as part of the process of establishing and maintaining treatment initiatives. This can be achieved in a variety of ways, including becoming known and accepted by families in the community.

Mm-hmm, I had to tell some of my clients or
potential clients who I was and why I'm here
and let them know that I talk Cree and, you
know, [that] I can feel relaxed and content when
I'm sitting in a house, you know and just to get
to know them. I did this to build up the trust first
and when that happened, it took a long time ...
people would come .... (Participant 17)

Participants cautioned that given a lack of trust, engagement can be a lengthy process that begins by going into the community and meeting people; this may involve visiting dozens of homes and listening to a multitude of stories, opinions, folklore and legends. One participant stated, "Mm - mm Listen to their [community members] stories. Everybody has a story (Participant 13)." By actively listening to their stories, the social worker can develop a greater appreciation for his/her understanding of events, history, difficulties and ideas about intervention, which in turn can be incorporated into the content of the initiative. This process provides community members with a sense of participation in the initiative and ownership of it, which may foster trust between the social worker and the community.

\section{Be Known in the Community}

In addition to knowing the community, the community would want to know the social worker. Consequently, community members seek reassurance that the social worker is genuine, trustworthy, and unassuming. In this vein, a participant provided the following advice for social workers:

$$
\begin{aligned}
& \text { Not acting good, just acting as the way you } \\
& \text { [social worker] are. And I find that one of the } \\
& \text { most important areas is just being yourself ... } \\
& \text { and accepting people for who they are, just the } \\
& \text { way they are, is another important thing that I } \\
& \text { found in establishing trust. (Participant 10) }
\end{aligned}
$$

Participants denoted that First Nations people want reassurance that the social worker will come to their community with an attitude that is informed and insightful. They want a person who will be respectful and knowledgeable about their history, tradition, culture and political situation. A frustrated participant stated:

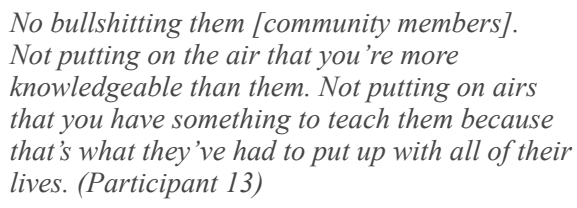

These characteristics can be demonstrated in a variety of ways. The social worker can actively listening to peoples' opinions and stories, and participate in many of their traditions and rituals. Rituals could include sweats, Sundance ceremonies, traditional feasts, dream quests, funerals and walks to name a few. By participating in these rituals and traditions, the social worker will demonstrate interest and respect for the individual, family and community.

\section{Be There During the Ups and Downs}

The social worker can enhance trust by being adaptable and flexible in the design and delivery of service. This could include performing duties that extend beyond the formal mandate of the initiative. A nurse from a northern Alberta community stated:

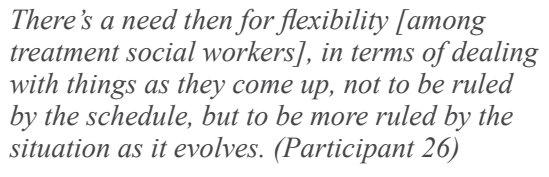

As there are few resources in First Nation communities, participants suggested that the social worker must deal with this reality and be prepared to address 


\section{Loss of Trust Among First Nation People}

the safety and concerns of all family members. This expectation goes far beyond the mandate often faced by social workers working in more mainstream settings. The data suggest that in First Nations communities the social worker must accept this expanded role and 'be there' during the times of need, as suggested in the following statement;

... telling them [the entire family unit] that you are here for them, I myself think that's what it is. That is what it takes [to earn the trust of the family and community]. (Participant 4)

Participants indicated that First Nations people want a promise from the social worker that he or she will make a reasonable commitment to the safety and health of all. A nurse reports on her conclusions:

\begin{abstract}
[The child care treatment social workers should] ... also make sure that when you are here that you do everything that you can to try and help, make people know that you are interested and that you want to do anything you can to help them out. If people can pick up on that then you get their trust. (Participant 26)
\end{abstract}

The social worker must be prepared to offer a broader range of services to family members, especially when working in communities that have few formal resources.

\section{Make a Long Term Commitment to the Initiative}

There are other expectations placed on the social worker in order to enhance trust. Participants suggested that in some First Nations communities there is a significant and sudden turnover of professionals. As a result, community members are reticent to make disclosures or to trust in treatment initiatives when there is a possibility that the social worker will not be there for the duration of a project. A predominate message especially among female participants was that despite the slow pace of change and the difficulty with engagement, social workers must be prepared to 'stick it out' for the duration of the initiative. A participant described the persistence required:

Like all September, October, November, December, January, like, five months I went every Tuesday and whether they [group participants] showed up or not, like, I still went, ... you open the door and you make coffee and hopefully someone else comes and you can have a meeting. Sometimes there's only two of you. (Participant 8)

Unmistakably, participants indicated that First Nations people want and deserve the reassurance that the social worker will be committed for the duration of an initiative and 'stay the course'.

Well, they [group participants] are looking for someone [group social worker] who is going to definitely be there ... [for the complete length of the program and for the safety needs of the entire family], if you're [group social worker] going to present your ideas and they [group participants] like your ideas, they want to know that you're going to commit to following through on them. Unfortunately, what happens a lot of times in communities is people [care providers] come and go, come and go and come and go ... (Participant 26)

Participants reported that social workers can instill trust by showing an interest and making a long-term commitment to the community.

\section{Maintain Confidentiality}

For many participants, trust was closely linked to confidentiality. Confidentiality appeared to be a persistent and menacing concern for many participants. They stated that community members were concerned that the social workers would indiscriminately divulge clinical information to other community members. This was a particularly worrisome concern for participants when the social worker was from their community.
I find that when they have community members working in positions of high confidentiality that they don't trust them and they feel that, perhaps, if that person were to go on a drunk or if that person were to fall off the wagon or see them they would judge them or they would tell their brothers, sisters or cousins. (Participant 7)
First Nations communities are often very small, closed and isolated, where almost everyone is related; conditions that cause participants to be concerned about rumors and gossiping. A participant stated: "Because we, there's so much rumoring and gossiping, you know, when you live in the community ... (Participant 16)."
While another stated:

$$
\begin{aligned}
& \text {... to recognize that he or she [social worker] } \\
& \text { is not, like, [going to gossip] everything is } \\
& \text { confidential. There is not going to be any } \\
& \text { gossiping. (Participant 7) }
\end{aligned}
$$$$
\text { confidential. There is not going to be any }
$$

Community members fear that if indiscriminate disclosures were to become public knowledge there would be unrelenting shame for individuals and families. One participant described such a reaction.

$$
\begin{aligned}
& \text { Shame, embarrassment. .... It's an } \\
& \text { embarrassment. You don't want family members } \\
& \text { to know about it. You know -- if I tell you what's } \\
& \text { going on in my life what are you going do with } \\
& \text { it? (Participant } 34 \text { ) }
\end{aligned}
$$

Disclosure of this type of personal information would be a concern in any community, but in First Nations communities the consequences may be more enduring 


\section{First Peoples Child \& Family Review, Volume 3, Number 4, 2007}

because residents do not move significant distances from one locale to another. It is for these reasons that trust and confidentiality are so tightly intertwined.

\section{Discussion}

As a result of their traumatization and resulting loss of trust, some First Nations people have experienced a limited ability to be open, sharing and contributing to self, family, clan and community (Thibodeau, 2003). The data suggest and the literature supports the concept that when people are afflicted by such a loss, they do not participate in family and community activities, and appear passive and unavailable for meaningful social interaction (Mollering, 2001). Matsakis (1998, p.58) advises,

\section{Without adequate help, there is a tendency for traumatized [sic] persons to stay "stuck" in the mind-set of extreme distrust that existed at the time of the trauma ... [and] do not take into account current reality, they can cause numerous problems both in daily living and relationships.}

A lack of trust can have dramatic consequences for treatment initiatives. The role of immediate family and clan members in First Nations communities is broad and influential (Kiyoshk, 1996). Families are viewed as a place where members learn personal and social skills and to take risks (Nichols \& Schwartz, 1995). When a lack of trust limits these social interactions within the family, these core concepts are not conveyed to its members.

The consequences of this phenomenon can adversely affect the implementation of community based treatment initiatives. People who lack trust are less likely to endorse, seek out or support community based initiatives (Goodman et al. 1998). Participants indicated that when community members do attend program initiatives, aspects of engagement, disclosure, personal reflection, confrontation and other essential characteristics of effective group functioning may be compromised because of a guarded stance.

The harsh reality is that this is a phenomenon with no facile or singular solution. Interview participants identified five broad strategies which may begin to allay concerns related to a diminished level of trust, however, considerably more attention and study are required to develop broader and more comprehensive responses.

This study has implications for social workers practicing in First Nations communities. Social workers are busy at the best of times and are now being asked to implement innovative and culturally appropriate treatment initiatives while remaining cognizant and responsive to the issue of lost trust. As a result, workers must prepare themselves, their administrators, funders, tribal council members and supervisors for new standards of clinical practice, such as planning for a protracted engagement phase, providing extensive and ongoing contact with community members and providing a more extensive use of self. Workers must also educate and advocate for new methods of practice, which includes re-writing more reasonable time lines for treatment development and implementation, and redefining appropriate levels of engagement with their clients and community.

In this study the research team solicited the views of only service providers who were working on First Nations communities. The team did not interview clients or family members for their views on this subject nor for their recommendations. This study was limited by a relatively small and homogeneous sample and the involvement of a non-First Nations researcher.

The significance of this concept and its implications for social workers implementing innovative treatment initiatives in First Nations communities cannot be overstated. Thus, the development of new methods of practice that will better serve the unique needs and expectations of First Nations people is warranted.

\section{References:}

Bineziikwe, O. (2005). Surviving the storm. The First Peoples Child \& Family Review, 2(1), 9 - 21.

Callahan, M. (1993). The Administrative and Practice Context: Perspectives from the Front Line. In B. Wharf (Ed.), Rethinking child welfare in Canada (pp. 64 - 97). Toronto: McClelland \& Stewart.

Callahan, M., Dominelli, L., Rutman, D. and Strega, S. (2003). Undeserving mothers: Lived experiences of young mothers in or from government care. In K. Kufeldt \& B. D. McKenzie (Eds.), Child Welfare Connecting Research, Policy and Practice (pp. 249-260). Waterloo, ON: Wilfrid Laurier University Press.

Cameron, G. (2003). Promoting Positive Child and Family Welfare. In K. Kufeldt \& B. D. McKenzie (Eds.), Child Welfare Connecting Research, Policy and Practice (pp. 79-99). Waterloo, ON: Wilfrid Laurier University Press.

Collier, K. (1993). Social work with rural peoples: Theory \& practice (2nd ed.). Vancouver, B.C.: New Star Books.

Cournoyer, D., \& Klein, W., (2000). Research methods for social work. Needdham Heights, MA. Allyn and Bacon.

Creswell, J. W. (2003). Research design: Qualitative, quantitative, and mixed methods approaches. (2nd Ed). Thousand Oaks, CA: Sage

Crowshoe, R., \& Mannesschmidt, S. (2002). Akak'stiman. Calgary, Alberta: University of Calgary Press.

Deutsch, C. P. (1981). The Behavioural Scientist: Insider and Outsider. Journal of Social Issues, 37, 172-191. 


\section{Loss of Trust Among First Nation People}

Edwards, E. D., \& Edwards, M. E. (1980). American Indians: Working with individuals and groups. Social Casework: The Journal of Contemporary Social worker, 25(4), 498 -506.

Field, P. A., \& Morse, J. M. (1985). Nursing research: The Application of Qualitative Approaches. Rockville: Aspen Systems corp.

Fukuyama, F. (1995). Trust: The social Virtues and the Creation of Prosperity. New York: Free Press.

Geoffrion, S., \& Scarth, S. (1995). Support and Prevention Programming: Themes, Policy Implications, and Research Agenda. In J. Hudson \& B. Galaway (Eds.), Child welfare in Canada: research and policy implications (pp. 187 - 191). Toronto: Thompson Educational.

Goodman, R.M., Speers, M.A., McLeroy, K., Fawcett, S., Kegler, M., Parker, E., et al. (1998). Identifying and Defining the Dimensions of Community-Capacity to Provide a Basis for Measurement. Health and Education \& Behavior, 258-278.

Kiyoshk, R. (1996). Stopping the Violence: Changing families, changing futures. Benwell Atkins Ltd.

Labaree, R. V. (2002). The Risk of Going Observationalist. Negotiating the Hidden Dilemmas of Being an Insider Participant Observer. Qualitative Research, 2(1), 97 -122.

LaRocque, E. D. (1993). The Path to Healing. Ottawa, ON: Canada Communication Group Publishing.

Lee, B. (1997). Pragmatics of Community Organization. (2nd ed.). Toronto, ON: Commonact PRESS.

Levy, R. and Hollan, D. (1998). Person-Centred Interviewing and Observation. In H. Russell Bernard (Ed.), Handbook of Methods in Cultural Anthropology (pp.333-364). Walnut Creek, Altamira.

Matsakis, A. (1998). Trust After Trauma. Oakland: New Harbinger Publications.

McCosker, H., Bernard, A., \& Gerber, R. (2001). Undertaking sensitive research: Issues and Strategies for Meeting the Safety Needs of All Participants. Qualitative Social Research, 2(1), 1.
McKenzie, B., \& Hudson, P. (1985). Native children, child welfare, and the colonization of native people. In K. L. Levitt \& B. Wharf (Eds.), The Challenge of child welfare (pp. 125 - 141). Vancouver: University of British Columbia Press.

Miles, M., \& Huberman, A. (1994). Qualitative data analysis. (2nd Ed.). Thousand Oaks, CA: Sage.

Mollering, G. (2001). The Nature of trust: From George Simmel to a Theory of Expectation, Interpretation and Suspension. Sociology, 35(2), 403- 420.

Nichols, M. P., \& Schwartz, R. C. (1995). Family therapy: Concepts and methods. Boston, Mass: Allyn and Bacon.

Patton, M.Q. (1990). Qualitative evaluation and research methods (2nd Edition). Newbury Park: Sage.

Pecora, P. J. (1995). Assessing the Impact of Family-Based Services. In J. Hudson \& B. Galaway (Eds.), Child welfare in Canada : research and policy implications (pp. 100-112). Toronto: Thompson Educational.

Proulx, J., \& Perrault, S. (2000). No Place for Violence: Canadian Alternatives. In J. Proulx \& S. Perrault (Eds.), Aboriginal Women and the Justice System. Halifax, NS: Fernwood Publishing Company.

Reichardt, C. S., \& Cook, T. D. (1992). Feminist Methods In Social Research. New York: Oxford University Press.

Royal Commission on Aboriginal Peoples. (1996). Report of the Royal Commission on Aboriginal Peoples. Ottawa, ON: Queens Printer.

Strauss, A., \& Corbin, J. (1998) Basics of qualitative research: Techniques and procedures for developing grounded theory. Thousand Oaks, CA: Sage.

Thibodeau, S. (2003). A Study of the Problematics of Implementing Initiatives that Prevent Violence Against Women In Aboriginal Communities. Unpublished Doctoral Thesis. University of Manchester, Manchester, UK.

Wharf, B. (1993). Rethinking child welfare In B. Wharf (Ed.), Rethinking child welfare in Canada (pp. 210 - 230). Toronto: McClelland \& Stewart. 